\title{
GYMNASTICS - AN ATRACTION FOR STUDENTS AT RISK OF SCHOOL DROPOUT TO PARTICIPATE IN EXTRACURRICULAR ACTIVITIES
}

\author{
Vasilica GRIGORE $^{1}$, Ana-Maria GAVOJDEA ${ }^{1 *}$ \\ ${ }^{1}$ National University of Physical Education and Sport, Faculty of Physical Education and Sport, Bucharest, \\ Romania \\ *Corresponding author: anagavojdea@gmail.com
}

https://doi.org/10.35189/dpeskj.2020.59.2.6

\begin{abstract}
Lately, gymnastics has become one of the branches of sport most frequently used in various human activities focusing on health and social integration. Nowadays, when we have so many opportunities for leisure, participating in gymnastics activities represents a real challenge for different population categories (children, youngsters, elders). The present study looks at the problematic of possible influences of Aerobic Gymnastics on the motivation and attachment of middle-school students to classes that approach this subject matter. We are mainly interested in the participation of students who are dealing with social exclusion and a high risk of school dropout from the perspective of their freedom of choice and desire to learn and practise the specific content together with the rest of the group. Studying the literature and official documents represents the main method used for conducting the research. Other methods: pedagogical observation, conversation and primary statistics. The analysed group was composed of middle-school students from School no. 162 in Bucharest. All members of the group are facing social exclusion and a high risk of dropping out of school and are participants in the extracurricular activities involving Aerobic Gymnastics organized within the school. The results of the study support the idea according to which the steps of Aerobic Gymnastics, the music and practising together with the others can represent an important means of action to increase the level of motivation, enjoyment and desire related to participation in these specific types of activities.
\end{abstract}

Keywords: gymnastics, inclusion, exclusion, school dropout.

\section{Introduction}

Social inclusion and social exclusion are two opposing terms generally used together. Thus, social inclusion is defined in relation with social exclusion and vice-versa.

Mohammadi (2019) defines social exclusion as a complex and multidimensional process that implies the absence or denial of resources, rights, goods and services, and the inability to participate in regular social relationships and activities available to the vast majority of people, regardless of whether these are economic, social, cultural or political.

Considering the complexity and multitude of aspects involved, Brar (2018) says that social exclusion implies different contexts and different sets of factors, i.e. historical, sociological, economic, political, sexual, biological or racial. Through the opinions expressed by Ponic and Frisby (2010) regarding social inclusion, we understand that this is also a process but, as opposed to exclusion, inclusion focuses on constant engagement in a relationship through active collaboration and, when referring to different activities, all participants are allowed to take decisions and get involved in the communities to which they belong.

When we look at the policies and action plans developed, we can conclude that these aspects are highly relevant on both a global and national scale. The aforementioned actions 
aim to identify the issues in nowadays society, highlight their causes and determine the factors behind them as well as outline the necessary measures and further directions for taking action.

Some of these problems are poverty eradication and elimination of all forms of discrimination and social exclusion that may eventually lead to school dropout.

Referring to school and students, school dropout represents a particular issue that gets special attention from policy-makers as well as everyone working in the field of education. School dropout and social exclusion are co-dependent. School dropout can be a consequence of extreme scholastic failure. It is a complex phenomenon (individual, social, institutional, economic, etc.) that ends with early school leaving without getting a qualification or training attested (Popescu, 1991), which marks the failure of adaptation seen as a mutual process, i.e. interdependent relationships between students and school, thus leading to a progressive increase in the number of children who drop out of school (Stoltz, 2000).

Sahin et al. (2016) have identified 5 categories of causes that result in school dropout. Based on the information provided by the authors mentioned above, these can be: familyrelated causes, causes related to school in general or certain behaviours of the principal and teachers, causes directly related to the student, contextual causes and environmental causes. These 5 categories led to the development of 15 main themes related to: family problems, ignoring absenteeism, view of education, economic issues, family-child relationship, principal-student relationship, teacher-student relationship, teacher's in-class behaviours, attitude towards absence, school structure, negative school ambiance, adaptation to school, individual reasons, relationship with the environment and environmental factors.

Referring to the numerous studies conducted, Branson et al. (2014), Adam et al. (2016) and Brar (2018) state that the most important factors revealed by many researchers, which cause school dropout, are: poverty, gender-related prejudices, bodily punishment, illness or death of one or both parents, having to look after younger siblings, being forced to work, pregnancy, marriage, distance from school.

In recent years, the phenomenon of school dropout has increased in Romania, which has drawn the attention of policy-makers and staff in the education field.

According to Eurostat (2020), in 2019, school dropout among youngsters with ages between 18 and 24 was $15.3 \%$, representing the lowest percentage recorded in the last decade. However, this is still a very high percentage when we look at the rest of the EU countries, Romania coming in fourth in a ranking of countries with the highest percentage of school dropout.

Concerning the school dropout rate in primary and lower secondary education in the academic year 2016-2017, it was 1.6\%; however, there is a $1.2 \%$ difference in score between rural and urban areas (Ministerul Educației Naționale [Ministry of National Education], 2018).

All data presented above have led to reconsidering sports as a motivating factor and an important tool for educational and integrative action.

Thus, through its multiple educational and moral valences, sports are now regarded worldwide as a means to establish the basis of social integration, to enhance relationships between individuals who come from different cultural and ethnic environments, to promote equality. Many countries have developed programmes, projects and studies related to the 
social integration of refugees, immigrants, people with disabilities etc., using sports activities. Among these, we mention: Germany (Michelini et al., 2018; Özgüzel \& Hasirci, 2019; Mohammadi, 2019), Spain (Carter-Thuillier et al., 2019), China (Chen \& Liu, 2020), Sweden (Ekholm \& Lindström Sol, 2020; Ekholm et al., 2019), Australia (Toffoletti \& Palmer, 2014), Belgium (Van der Veken et al., 2020), Greece (Morela et al., 2019), Romania (Grigore \& Stanică Gavrilescu, 2018; Stănescu et al., 2020). The problematic of social integration through sports for people with disabilities was studied by McConkey et al. (2013), Ferreira et al. (2018), Albrecht et al. (2019), McConkey et al. (2019). In Romania, important studies were conducted by Bălan and Marinescu (2015), especially referring to intellectual disabilities.

Lately, gymnastics has become one of the branches of sport most frequently used in different human activities focusing on health and social integration.

Nowadays, when we have so many opportunities for leisure, participating in gymnastics activities represents a real challenge for different population categories (children, youngsters, elders).

As a subject - part of the curriculum, gymnastics is also important because it ensures a student-centred teaching process in a motivating and attractive learning context, has formative orientation through the development of designed and expected skills, adopts participatory strategies, approaches individualised contents adaptable to both the possibilities and interests of students and the material conditions that the school can provide.

Of all branches of gymnastics, Aerobics represents an option for many people, including extracurricular sports activities.

Aerobic Gymnastics involves a wide range of movements and elements that can generate a multitude of combinations, dynamic structures and choreographies to music (Pop \& Ciomag, 2014). Performing movements accompanied by music helps to develop the rhythm and musical sense of the participants and makes the activity much more attractive, fun and accessible (Ciomag \& Dinciu, 2013).

Through its content, Aerobic Gymnastics is looking to fulfil motor-functional, healthrelated, aesthetic, socio-psychological objectives (Mustedanagić et al., 2016). Numerous studies on this topic identify the following benefits derived from the practice of Aerobic Gymnastics: improving the functional capacity of the cardiovascular, musculoskeletal and nervous systems (Mustedanagić et al., 2016; Zhang et al., 2017), reducing excess body fat, reducing bodyweight, increasing lean body mass (Pruneanu et al., 2012; Mustedanagić et al., 2016; Trajković et al., 2016), reducing states of depression, anxiety, fatigue, isolation, frustration (Ciomag \& Dinciu, 2013; Yang \& Chen, 2018), improving self-image and confidence (Ciomag \& Dinciu, 2013; Rokka et al., 2019).

Aerobic Gymnastics develops not only motor skills but also motor memory. Using Aerobic Gymnastics during Physical Education and Sports classes or during extracurricular activities can create an environment favourable for learning (by learning choreography) and increase the desire to actively participate in the lesson (by assigning roles and tasks to each student) (Rokka et al., 2019). Those mentioned above lead to increased motivation, which can help students to improve their overall learning outcomes (Cuevas et al., 2016).

We also consider that applying a differential curriculum that also includes gymnastics allows the choice of educational paths suitable to the interest and abilities of students, 
organizing components for a more efficient educational intervention with the aim of increasing motivation to participate in school activities (including sports activities) and preventing students from abandoning school.

\section{Methodology}

Our scientific approach started from an interrogation concerning gymnastic activities as a free choice and the desire to learn and practise specific content together with the other members of the classroom.

Consequently, in conducting this study, we aimed to outline the process of enrolling in the extracurricular activity with a gymnastics theme, the ways of relating to others and the pleasure induced by performing the programme.

The methods used are: direct observation, conversation, analysis of documents corresponding to the activity and primary statistics.

\section{Participants}

The subjects of the research were 17 students in the 5th grade from School no. 162 in Bucharest, members of the target group of the project "Sustainable Social and Educational Integration through Sports Activities" - PNP 001.

They formed a group of different ethnicities (including Roma) for whom we planned 5 extracurricular activities focused on Aerobic Gymnastics for beginners, but only 4 activities were organized. These 4 extracurricular activities were carried out on the following dates: 30.01.2020, 06.02.2020, 13.06.2020 and 20.06.2020.

\section{Procedure}

The intervention programme mainly consisted in teaching and learning the basic steps of Aerobic Gymnastics (March, Jog, Skip, Lunge, Jumping Jack, Knee Lift and Kick) and auxiliary steps (Step Touch, Grape-Fine and V-Step), applying them in different personal combinations and putting them together by the groups of students, as well as role play.

The objectives were to develop motor and applicative skills by demonstrating the learned steps, designing combinations of steps as a result of the group activity and, most importantly, by taking responsibility for fulfilling the task from the teacher's position.

\section{Results}

Direct observation has revealed that students have a satisfactory level of understanding the structure of a physical education class and the simple movements of segments, as well as the ability to execute linked movements in order to prepare for effort. Their attitude and implication proved that they were willing to exercise. During the process of teaching and practising the steps, which was completely new to them, we observed different attitudes: some engaged in completing the task without hesitation ( 3 participants), a large part of them showed restraint in exercising new movements but still gave it a try (6 participants), while 
others completely stopped but maintained their positions and observed the others (4 participants).

During the activities, the number of those withdrawing from the activity decreased, and we noticed that students of Roma ethnicity were incorporated in various groups. Without claiming very rigorous recordings but only on the basis of careful observation of behaviours, we concluded that the created ambiance, the musical background, the musicality and dancing skills of Roma students brought the participants closer together and all problems of cooperation disappeared by the time we were carrying out the third activity.

If, for the first two activities, children formed groups of the same ethnicity, later on the relaxed ambiance and music contributed to the collaboration between students of different ethnicities. Moreover, Roma students stood out from the group and were appreciated by their colleagues for their musicality and rhythmicity.

Our purpose during conversations with students was to understand whether the choice to join the gymnastics class was their own or they were guided/directed towards taking the class. With that in mind, we considered that active participation in the activities could be a good indicator of students' intentions and reflect their freedom of choice.

We calculated the ratio of participants from the total target group of 5th graders. We considered the percentage of those present versus those absent for each activity, the percentage of those present in at least one activity against those absent, the number of active participations - number of activities and the attendance of each student against the total number of activities.

Figures 1-7 present data referring to student participation in activities.

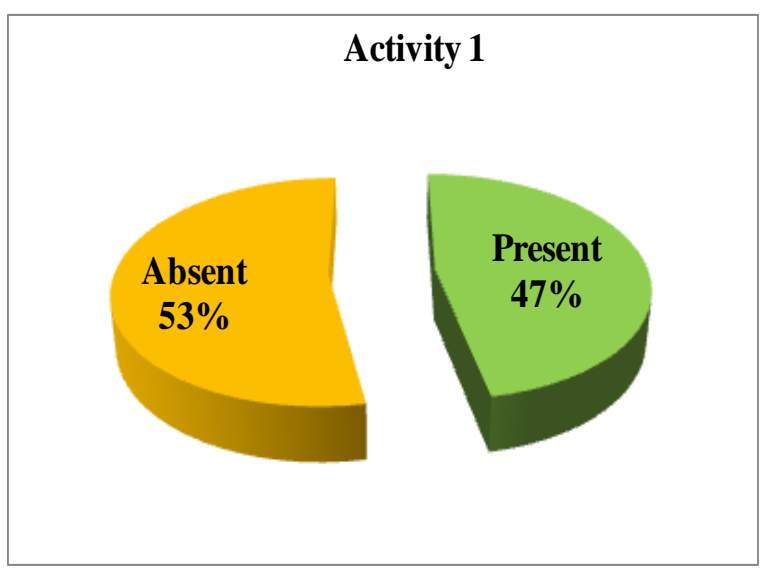

Figure 1. Participation in the 1 st activity

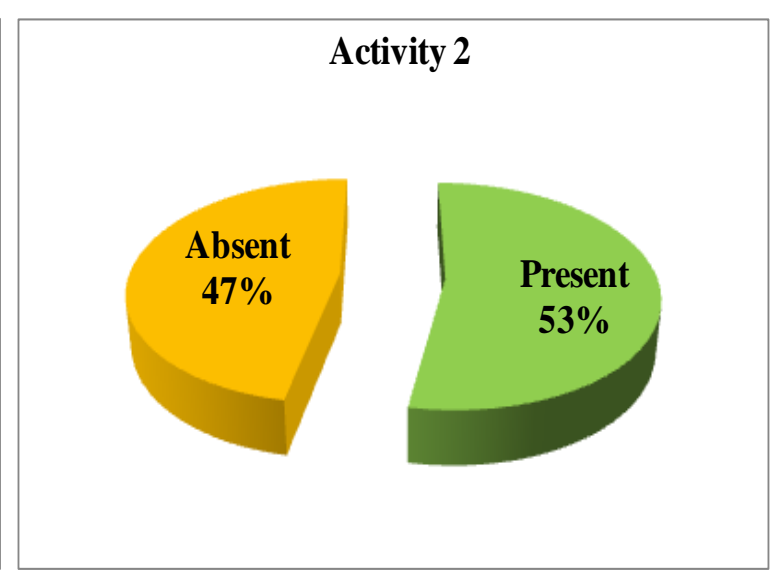

Figure 2. Participation in the 2nd activity 


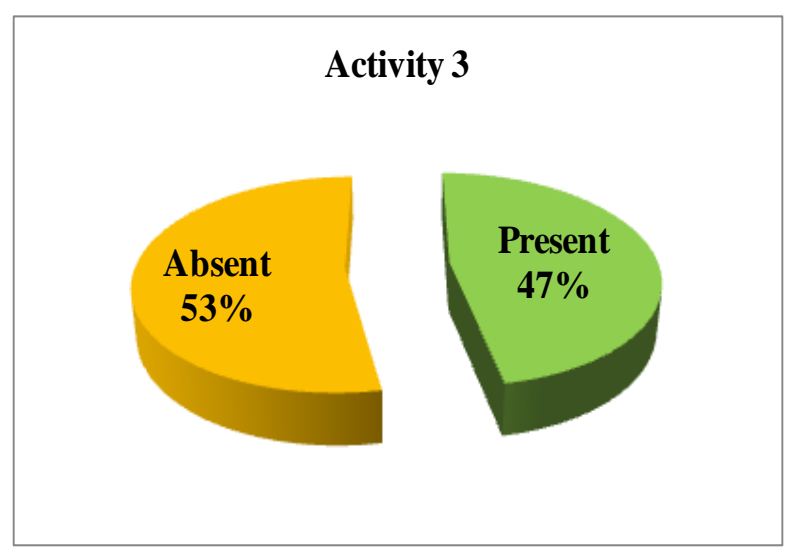

Figure 3. Participation in the 3rd activity

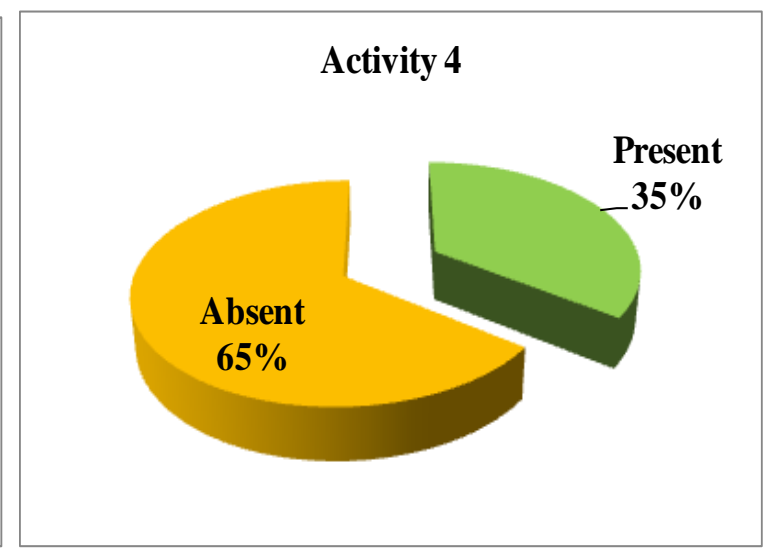

Figure 4. Participation in the 4th activity

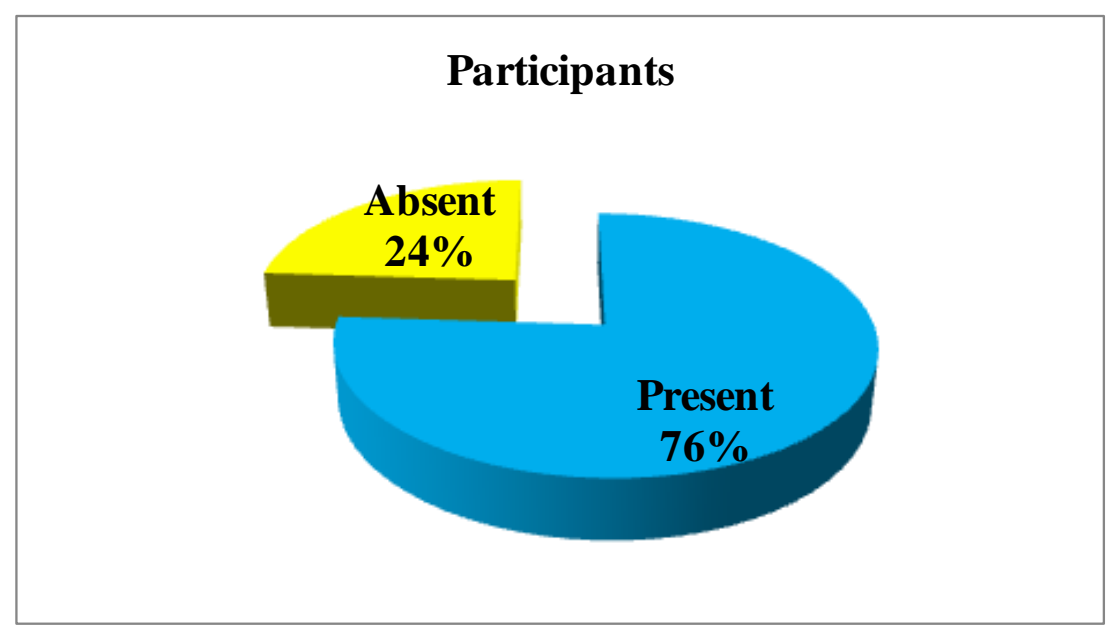

Figure 5. Student participation in at least one activity

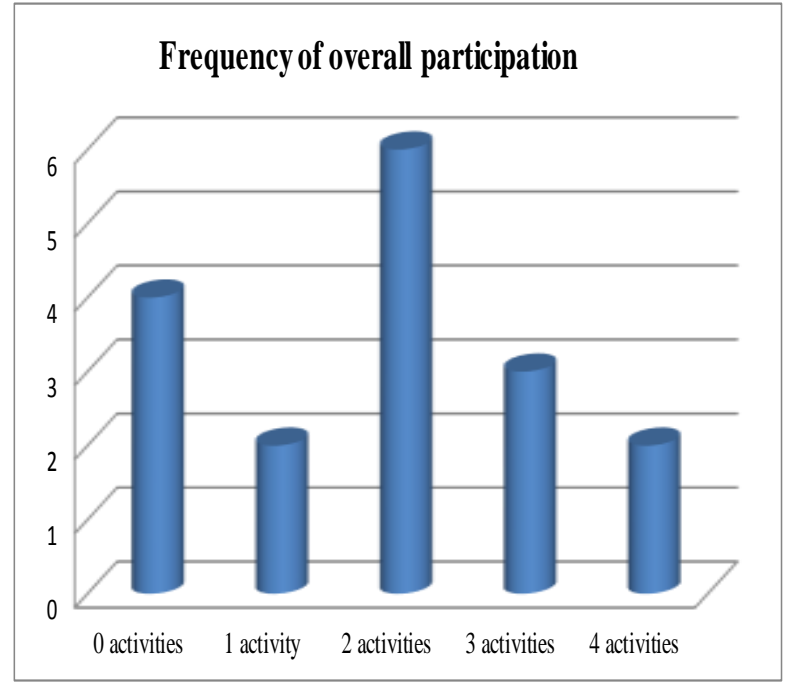

Figure 6. Number of participations - number of students

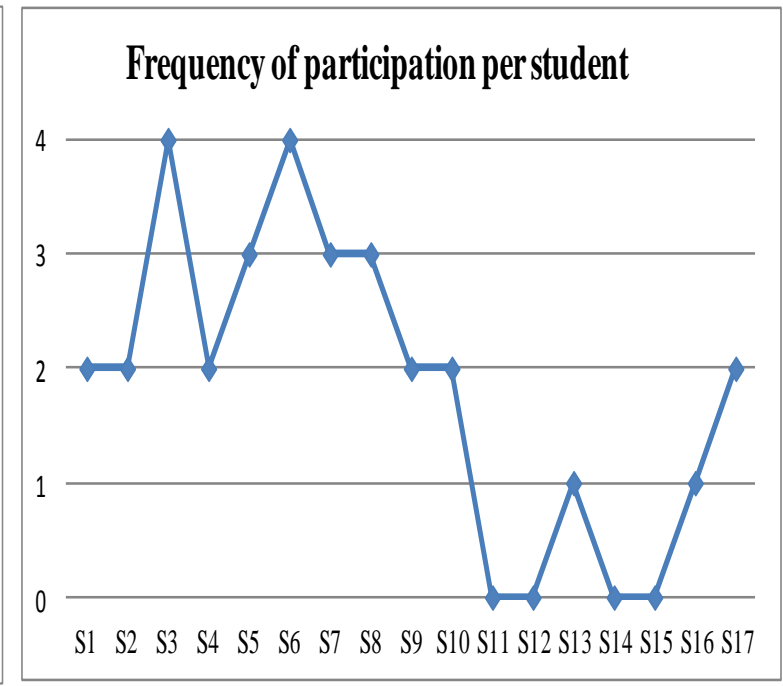

Figure 7. Frequency of participation in activities per student 
The period chosen for extracurricular activities could not offer an entirely favourable context since it overlapped the seasonal flu period at its peak, which meant that large numbers of students were absent from school. Because of that, we organized only 4 activities where we had a participation of maximum 53\% and minimum of $35 \%$ of all students. It is important to mention that, out of the total of 17 students (100\%) in the 5th grade identified as having a risk of school dropout, only $24 \%$ (4 students) did not participate at all (Figure 5), while the rest of $76 \%$ (13 students) participated in at least one and maximum 4 activities. The total number of absentees includes recorded medical exemptions and absences from all lessons in the daily schedule.

Figure 6 presents the number of participants per activity and indicates that most of them attended activity 2, which was due to the fact that, at the time, part of the medically exempt students returned to class but also because of the content of activity 1 and the dynamic approach of the lesson, which worked as a motivating factor. Analysing the participation of each student (Figure 7 ), we can identify a group of 6 students $(46.15 \%$ of the total of students having participated at least once) who managed to be present in two activities (50\% of all activities organized) and also a group of 5 students (38.46\%) who participated in 3 and 4 activities. Considering that a total of 4 activities were organized (100\%), the three participations recorded (75\%) for students with codes S5, S7 and S8 represent $23.07 \%$ of the total number of those who participated at least once.

Also, due to the special situation determined by the seasonal flu, there are two participants in the group (representing $15.38 \%$ of the total of those who participated at least once), coded S3 and S6, who attended all activities (100\%).

The conversation method was applied in different moments, usually at the end of the activity but also at the beginning of the next one. Students were open to communicate and provide information about what they learned/practised during a specific activity. This allowed us to understand what they liked and disliked, what they would like to practise further and whether they were satisfied with what they managed to execute but also the content offered.

The answers provided indicated a good level of satisfaction. When asked about the content of the activity, students declared that they were satisfied, enjoyed what they worked on and enjoyed the ambiance during the class; some were happy/unhappy about their colleagues' feedback regarding the choreographies they had put together.

Role play was their preferred activity. Each student in turn took the role of the teacher. When playing this role, they explained, demonstrated and commanded the execution of certain basic steps or sequences of steps using their own creativity. They specifically enjoyed playing the part of the teacher as they had a lot of fun communicating corrections and observations. We were pleasantly surprised by the attitude of peers playing the part of students, who listened to the teacher's commands and tried to execute them to the best of their abilities in order to receive positive feedback.

Students expressed their wish to have additional games included in the schedule of activities, so various versions of walking, running, jumping, rolling or tumbling were introduced. Also, students asked for more "kid games" and other similar activities.

When asked how they felt at the end of the class, students answered they felt fine, were 'dead tired' but enjoyed the activity and would like to participate in more sports activities. 


\section{Discussion and conclusion}

Applying a differential curriculum allows the choice for educational paths suitable to the interest and abilities of students, organizing components for a more efficient educational intervention in order to keep students active in the system and reduce premature school dropout.

The research results lead us to support the opinions of authors: Ciomag and Dinciu (2013), Pop and Ciomag (2014), Rokka et al. (2019), according to which, on top of the multiple benefits presented earlier, Aerobic Gymnastics is a type of physical activity that can be organized and carried out with larger groups of people, which recommends it as a tool for social integration.

The pedagogical methods and procedures used for teaching and practising contents specific to Aerobic Gymnastics should be adapted to the age and level of the groups of students. These methods, together with work formations, specific tasks and music represent efficient tools that can be used in different extracurricular activities to disinhibit students, remove psychological and social barriers and increase student attachment to this type of activities and implicitly to school. All this can lead to retaining a higher number of students in the educational system and avoiding premature school dropout. The freedom of expression, relaxed ambiance, fair play, appreciation and acknowledgement of the best specific to Physical Education and Sports can induce a state of psychological wellbeing as a consequence of the feelings of pleasure experienced during the physical activity but also the wish to be together with the rest of the group and enjoy activities together. We consider that, even if we carried out only a reduced number of activities that involved a small number of participants at School no. 162 in Bucharest, these represent a good start for the development of a range of extracurricular activities with content linked to that of Physical Education classes as well as completely new and surprising content for the students, which can ensure a friendly environment and determine students to consider school a genuine support in fulfilling their wishes.

\section{Acknowledgment}

This paper was achieved under the auspices of the National University of Physical Education and Sport in Bucharest, coordinator of the project "Sustainable Social and Educational Integration through Sports Activities" - PNP 001.

\section{Authors' Contributions}

All authors have equally contributed to this article.

\section{References}

Adam, S., Adom, D., \& Bediako, A. B. (2016). The major factors that influence basic school dropout in rural Ghana: The case of Asunafo South District in the Brong Ahafo Region of Ghana. Journal of Education and Practice, 7(28), 1-8. 
https://files.eric.ed.gov/fulltext/EJ1118546.pdf

Albrecht, J., Elmose-Østerlund, K., Klenk, C., \& Nagel, S. (2019). Sports clubs as a medium for integrating people with disabilities. European Journal for Sport and Society, 16(2), 88110. https://doi.org/10.1080/16138171.2019.1607468

Bălan, V., \& Marinescu, G. (2015). Sports - Means of social inclusion for Down's syndrome patients. Romanian Journal for Multidimensional Education, 7(2), 111-117. http://dx.doi.org/10.18662/rrem/2015.0702.10

Branson, N., Hofmeyr, C., \& Lam, D. (2014). Progress through school and the determinants of school dropout in South Africa. Development Southern Africa, 31(1), 106-126. https://doi.org/10.1080/0376835X.2013.853610

Brar, N. K. (2018). A comparative study of the exclusion of girl child in school education in India and Punjab. MIER Journal of Educational Studies, Trends and Practices, 8(2), 213222. http://www.mierjs.in/ojs/index.php/mjestp/article/view/180/162

Carter-Thuillier, B., López-Pastor, V., Gallardo-Fuentes, F., \& Carter-Beltran, J. (2019). Inmigración y deporte escolar: Un caso de estudiantes latinoamericanos en España [Immigration and school sports: A case of Latin-American students in Spain]. Journal of Sport and Health Research, 11(Suppl 2), 41-52. http://www.journalshr.com/papers/Vol\%2011_suplemento2/JSHR_V11_SUPL2_04.pdf

Chen, Q., \& Liu, T. (2020). The effectiveness of community sports provision on social inclusion and public health in rural China. International Journal of Environmental Research and Public Health, 17(2): 597. https://dx.doi.org/10.3390\%2Fijerph17020597

Ciomag, R. V., \& Dinciu, C. C. (2013). Aerobics - Modern trend in the university educational domain. Procedia - Social and Behavioral Sciences, 92, 251-258. https://doi.org/10.1016/j.sbspro.2013.08.668

Cuevas, R., Garcia-Lopez, L. M., \& Serra-Olivares, J. (2016). Sport education model and self-determination theory: An intervention in secondary school children. Kinesiology International Journal of Fundamental and Applied Kinesiology, 48(1), 30-38. https://doi.org/10.26582/K.48.1.15

Ekholm, D., \& Lindström Sol, S. (2020). Mobilising non-participant youth: Using sport and culture in local government policy to target social exclusion. International Journal of Cultural Policy, 26(4), 510-523. https://doi.org/10.1080/10286632.2019.1595607

Ekholm, D., Dahlstedt, M., \& Rönnbäck, J. (2019). Problematizing the absent girl: Sport as a means of emancipation and social inclusion. Sport in Society, 22(6), 1043-1061. https://doi.org/10.1080/17430437.2018.1505870

Eurostat. (2020). Early leavers from education and training, age group 18-24. https://ec.europa.eu/eurostat/tgm/table.do?tab=table\&init=1\&plugin=1\&pcode=tesem 020 \&language $=\mathrm{en}$

Ferreira, D., Serrano, J., Petrica, J., Honório, S., Mesquita, M. H., \& Batista, M. (2018). Integração social de atletas de desporto adaptado na modalidade de atletismo [Social integration of adapted sports athletes in athletics]. ÁGORA para la Educación Física y el Deporte, 20(2/3), 256-278. https://doi.org/10.24197/aefd.2-3.2018.256-278

Grigore, V., \& Stanică Gavrilescu, A. (2018). School abandonment at primary and secondary levels in the rural Vrancea county. The European Proceedings of Social \& Behavioural Sciences, XXXVI, 405-412. https://doi.org/10.15405/epsbs.2018.03.54

McConkey, R., Dowling, S., Hassan, D., \& Menke, S. (2013). Promoting social inclusion through unified sports for youth with intellectual disabilities: A five-nation study. Journal of Intellectual Disability Research, 57(10), 923-935.

https://doi.org/10.1111/j.1365-2788.2012.01587.x 
McConkey, R., Pochstein, F., Carlin, L., \& Menke, S. (2019). Promoting the social inclusion of players with intellectual disabilities: An assessment tool for sport coaches. Sport in Society, 22, 1-10. https://doi.org/10.1080/17430437.2019.1673369

Michelini, E., Burrmann, U., Nobis, T., Tuchel, J., \& Schlesinger, T. (2018). Sport offers for refugees in Germany. Promoting and hindering conditions in voluntary sport clubs. Society Register, 2(1), 19-38. https://doi.org/10.14746/SR.2018.2.1.02

Ministerul Educației Naționale. (2018). Raport privind starea învățământului preuniversitar din România 2017-2018 [Report on the state of pre-university education in Romania 20172018]. București: MEN.

Mohammadi, S. (2019). Social inclusion of newly arrived female asylum seekers and refugees through a community sport initiative: The case of Bike Bridge. Sport in Society, 22(6), 1082-1099. https://doi.org/10.1080/17430437.2019.1565391

Morela, E., Elbe, A.-M., Theodorakis, Y., \& Hatzigeorgiadis, A. (2019). Sport participation and acculturative stress of young migrants in Greece: The role of sport motivational environment. International Journal of Intercultural Relations, 71, 24-30. https://doi.org/10.1016/j.ijintrel.2019.04.003

Mustedanagić, J., Bratić, M., Milanović, Z., \& Pantelić, S. D. (2016). The effect of aerobic exercise program on the cardiorespiratory fitness and body composition of female college students. Facta Universitatis, Series: Physical Education and Sport, 14(2), 145-158. http://casopisi.junis.ni.ac.rs/index.php/FUPhysEdSport/article/view/1847/1344

Özgüzel, S., \& Hasirci, S. (2019). The importance of sport in integrating refugees into Germany. International Journal of Applied Exercise Physiology, 8(2), 1-7. https://doi.org/10.30472/ijaep.v8i2.573

Ponic, P., \& Frisby, W. (2010). Unpacking assumptions about inclusion in community-based health promotion: Perspectives of women living in poverty. Qualitative Health Research, 20(11), 1519-1531. https://doi.org/10.1177\%2F1049732310374303

Pop, C., \& Ciomag, V. (2014). The influence of aerobic gymnastics on the students' body image. Procedia - Social and Behavioral Sciences, 117, 129-135. https://doi.org/10.1016/j.sbspro.2014.02.190

Popescu, V. V. (1991). Succesul și insuccesul școlar: Precizări terminologice, forme de manifestare, cauze [School success and failure: Terminological specifications, forms of manifestation, causes]. Revista de Pedagogie, 12.

Pruneanu, M., Petreanu, A. \& Simion, G. (2012). The influence of aerobic gymnastics in improving the quality of life for female students in medical academic environments. Ovidius University Annals, Series Physical Education \& Sport/Science, Movement \& Health, 12(2 Suppl), 442-446.

https://www.analefefs.ro/anale-fefs/2012/issue-2-s/pe-autori/30.pdf

Rokka, S., Kouli, O., Bebetsos, E., Goulimaris, D., \& Mavridis, G. (2019). Effect of dance aerobic programs on intrinsic motivation and perceived task climate in secondary school students. International Journal of Instruction, 12(1), 641-654. https://doi.org/10.29333/IJI.2019.12141A

Sahin, S., Arseven, Z., \& Kiliç, A. (2016). Causes of student absenteeism and school dropouts. International Journal of Instruction, 9(1), 195-210. https://doi.org/10.12973/IJI.2016.9115A

Stănescu, M., Bota, A., Bejan-Mureșan, R., \& Corlaci, I. (2020). Sport activities in Romania - A tool for social innovation. Romanian Journal for Multidimensional Education, 12(1), 320-333. DOI: $10.18662 / \mathrm{rrem} / 216$

Stoltz, G. (2000). Eșec școlar - risc de eșec social [School failure - a risk of social failure]. București: Editura Victor. 
Toffoletti, K., \& Palmer, C. (2014). Muslim women and sport: Participation, consumption, representation. TASA 2014 Conference "Challenging Identities, Institutions and Communities".

https://www.academia.edu/27322393/Muslim_women_and_sport_participation_consumpt ion_representation

Trajković, N., Madić, D., Sporiš, G., Aleksić, A., \& Živčić-Marković, K. (2016). Impact of gymnastics program on health-related fitness in adolescent pupils. Science of Gymnastics Journal, 8(2), 157-166.

https://pdfs.semanticscholar.org/078a/3dfba1ab3ac967cef668506a6b8bd4285787.pdf

Van der Veken, K., Lauwerier, E., \& Willems, S. (2020). "To mean something to someone": Sport-for-development as a lever for social inclusion. International Journal for Equity in Health, 19(1), 1-13. https://doi.org/10.1186/s12939-019-1119-7

Yang, C. L., \& Chen, C. H. (2018). Effectiveness of aerobic gymnastic exercise on stress, fatigue, and sleep quality during postpartum: A pilot randomized controlled trial. International Journal of Nursing Studies, 77, 1-7. https://doi.org/10.1016/j.ijnurstu.2017.09.009

Zhang, H. J., Guo, X. T., \& Zhang, H. L. (2017). Effects of health education on cardiovascular system in middle-aged and elderly people - Take aerobic exercise for example. Eurasia Journal of Mathematics, Science and Technology Education, 13(11), 7483-7487. https://doi.org/10.12973/ejmste/79984 